\title{
Uji Efektivitas Pasta Gigi Pemutih terhadap Perubahan Warna Gigi Ekstrinsik
}

\author{
Cintia Bayahu, Damajanty H. C. Pangemanan, Christy N. Mintjelungan
}

\author{
Program Studi Pendidikan Dokter Gigi Fakultas Kedokteran Universitas Sam Ratulangi, \\ Manado, Indonesia \\ Email: cintiabayahu29@gmail.com
}

\begin{abstract}
Physical appearance has a major influence in determining the quality of individual social interaction, especially in terms of non-verbal interactions. Tooth color is one of the things that affect physical appearance. Various efforts to improve the aesthetics of tooth color should be studied further, including the use of whitening toothpaste. This study was aimed to determine the effectiveness of whitening toothpaste on extrinsic tooth discoloration. This was a true experimental study in the form of laboratory test. Coffee was used as a discoloring agent for teeth. Twentysix premolar teeth were immersed in coffee solution for 14 days. Then the samples were divided into four groups based on the toothpaste used. Initial measurements used the CIEL *a*b* digital dental photo technique. Brushing was carried out for 14 days, after which the tooth color was measured again. The paired sample t-test and the Wilcoxon test showed a significant change in $*$ $\mathrm{L}$ values in the group receiving $7 \%$ perlite, hydrated silica, and sodium bicarbonate $(\mathrm{p}=0.01$; $\mathrm{p}=0.001 ; \mathrm{p}=0.012)$. The Wilcoxon test showed no change in $* \mathrm{a}$ and $* \mathrm{~b}$ values in all whitening toothpaste groups $(\mathrm{p}>0.05)$. There was no significant change in the $* \mathrm{~L} * \mathrm{a} * \mathrm{~b}$ toothpaste ( $>0.05$ ). In conclusion, whitening toothpaste is effective against extrinsic tooth discoloration.
\end{abstract}

Keywords: extrinsic tooth discoloration; whitening toothpaste; tooth color

\begin{abstract}
Abstrak: Penampilan fisik memiliki pengaruh besar dalam menentukan kualitas interaksi sosial individu, terutama dalam hal interaksi non-verbal. Salah satu hal yang memengaruhi penampilan fisik individu ialah warna gigi. Berbagai upaya untuk meningkatkan estetika warna gigi harus dikaji lebih lanjut, termasuk penggunaan pasta gigi pemutih. Penelitian ini bertujuan untuk mengetahui efektivitas pasta gigi pemutih terhadap perubahan warna gigi ekstrinsik. Jenis penelitian ialah eksperimental murni (true experimental design) berupa uji laboratorik. Kopi digunakan sebagai bahan diskolorasi untuk gigi. Sebanyak 26 gigi premolar direndam dalam larutan kopi selama 14 hari. Sampel dibagi ke dalam empat kelompok berdasarkan pasta gigi yang digunakan. Pengukuran awal menggunakan teknik digital dental photo CIEL*a*b*. Penyikatan dilakukan selama 14 hari, setelah itu warna gigi diukur kembali. Hasil uji paired sample t-test dan Wilcoxon menunjukkan terdapat perubahan nilai $* \mathrm{~L}$ yang bermakna pada kelompok yang mendapatkan perlite $7 \%$, silica hydrated, dan sodium bicarbonate $(\mathrm{p}=0,01 ; \mathrm{p}=0,001 ; \mathrm{p}=0,012)$. Uji Wilcoxon menunjukkan tidak terdapat perubahan nilai *a dan nilai *b pada semua kelompok pasta gigi pemutih $(\mathrm{p}>0,05)$. Pada pasta gigi tanpa pemutih tidak didapatkan perubahan nilai $*^{*}{ }^{*} a * b$ yang bermakna $(p>0,05)$. Simpulan penelitian ini ialah pasta gigi pemutih efektif terhadap perubahan warna gigi ekstrinsik.
\end{abstract}

Kata kunci: perubahan warna gigi ekstrinsik; pasta gigi pemutih; warna gigi

\section{PENDAHULUAN}

Penampilan fisik memiliki pengaruh besar dalam menentukan kualitas interaksi sosial individu, terutama dalam hal interaksi non-verbal. Salah satu hal yang memengaruhi penampilan fisik individu adalah warna gigi. Masyarakat mulai menyadari bahwa 
warna gigi merupakan salah satu fitur fisik yang dapat memengaruhi penampilan. ${ }^{1}$ Sebuah penelitian yang dilakukan oleh Isiekwe dan Aikins ${ }^{2}$ tahun 2019 pada 420 mahasiswa di Universitas Lagos, Nigeria menunjukkan sebanyak $90 \%$ orang setuju bahwa warna gigi yang terlihat sehat dan bersih sangat berpengaruh terhadap penampilan fisik mereka. Bahkan, warna gigi begitu penting pada beberapa individu sampai dapat secara langsung memengaruhi kualitas hidupnya. ${ }^{3}$ Namun masih banyak masyarakat yang kurang puas dengan warna gigi yang dimilikinya.

Sebuah penelitian yang dilakukan oleh da Costa et $\mathrm{al}^{4}$ pada tahun 2017 di Brazil menunjukkan bahwa hanya $50 \%$ orang yang memiliki persepsi baik tentang estetika giginya, termasuk warna gigi. Sementara itu di Indonesia, penelitian Marheni ${ }^{5}$ pada tahun 2017 di Bali melaporkan bahwa sebanyak hampir $80 \%$ individu merasa tidak puas dengan kondisi estetika giginya, termasuk dengan warna gigi yang dimilikinya. Penelitian-penelitian tersebut menunjukkan bahwa ketidakpuasan terhadap estetika gigi, khususnya warna gigi, dapat ditemukan pada masyarakat di berbagai negara, termasuk Indonesia. Oleh sebab itu, berbagai upaya untuk meningkatkan estetika warna gigi harus dikaji lebih lanjut, termasuk penggunaan pasta gigi pemutih.

Pasta gigi adalah suatu bahan semiaqueous yang digunakan bersama sikat gigi untuk membersihkan deposit sekaligus memoles seluruh permukaan gigi. Pada dasarnya, pasta gigi hanya bersifat mencegah terjadinya perubahan warna gigi dengan membersihkan kotoran dan mencegah terbentuknya plak. Namun, beberapa pasta gigi dibuat mengandung agen yang dapat bersifat sebagai pemutih. Beberapa contoh bahan pemutih tersebut antara lain sodium karbonat, hidrogen peroksida, citroxane, dan hexametaphospate. Bahan-bahan tersebut ditambahkan dalam jumlah yang sedikit, tepatnya sekitar $0,05-0,5 \% .{ }^{6}$ Efektivitas pasta gigi pemutih ini pun telah sering kali diteliti.

Berdasarkan latar belakang ini terlihat bahwa warna gigi merupakan salah satu permasalahan kesehatan yang sangat pen- ting untuk diperhatikan karena berkaitan langsung dengan kualitas hidup individu. Sayangnya masih banyak individu yang merasa tidak puas dengan warna gigi yang dimilikinya. Hal ini membuat penulis tertarik untuk melakukan penelitian ini, sekaligus menjadikannya penting untuk dilakukan.

\section{METODE PENELITIAN}

Penelitian ini dilaksanakan pada bulan April-Mei 2021 di PSPDG Universitas Sam Ratulangi Manado. Jenis penelitian ini ialah eksperimental murni (true experimental design) berupa uji laboratorik dengan pre test-post test control group design. Besar sampel yang digunakan pada penelitian ini sebanyak 24 sampel gigi premolar maksila dan mandibula. Kriteria inklusi penelitian ini yaitu gigi permanen premolar 1 dan 2 rahang atas dan rahang bawah yang telah dicabut, mahkota utuh, bersih tanpa pewarnaan. Kriteria eksklusi pada penelitian ini yaitu karies email, hipoplasia email, dan gigi yang mengalami fluorosis.

Sampel penelitian yang telah dikumpulkan, dibersihkan terlebih dahulu dan diberi cat kuku warna putih bening pada bagian akar sampai dengan servikal gigi untuk mencegah terdepositnya larutan kopi kedalam tubuli dentin. Setelah itu, direndam dalam larutan kopi selama 14 hari lalu dilakukan pengukuran warna awal menggunakan teknik pengukuran digital dental photo CIE * $\mathrm{L}^{*} \mathrm{a} *$ b. Sampel dibagi menjadi empat kelompok secara acak. Masingmasing kelompok terdiri dari enam sampel.

Penyikatan gigi selama 14 hari dilakukan setelah pengukuran warna awal. Penyikatan gigi dilakukan menggunakan alat sikat gigi manual dengan tekanan sebesar $100 \mathrm{~g}$ atau setara dengan $1 \mathrm{~N}$ dan arah penyikatan mesio-distal. Penyikatan dilakukan dua kali sehari. Gigi disikat selama 3 menit dengan bulu sikat yang menyentuh seluruh permukaan gigi. Kelompok pertama disikat dengan pasta gigi pemutih yang mengandung bahan pemutih 0,7\% perlite; kelompok kedua disikat dengan pasta gigi pemutih yang mengandung silica hydrated; kelompok ketiga disikat dengan pasta gigi yang mengandung sodium 
bikarbonat; dan kelompok keempat disikat dengan pasta gigi tanpa bahan pemutih. Saat sampel tidak sedang disikat, sampel ditaruh di dalam inkubator yang bersuhu $37^{\circ} \mathrm{C}$ dan direndam dalam larutan saliva artifisial. Setelah gigi disikat selama 14 hari, dilakukan pengukuran warna kembali menggunakan teknik pengukuran digital dental photo $\mathrm{CIE} * \mathrm{~L} * \mathrm{a} * \mathrm{~b}$. Untuk mengetahui perbedaan efektifitas pasta gigi pemutih terhadap perubahan warna gigi, maka dilakukan analisis dengan uji paired sample t-test dan Wilcoxon $(p<0,005)$.

\section{HASIL PENELITIAN}

Tabel 1 memperlihatkan perubahan nilai kecerahan warna gigi yang bermakna pada kelompok yang mendapatkan perlite $7 \%$, silica hydrated, dan sodium bicarbonate $(\mathrm{p}=0,01 ; \mathrm{p}=0,001 ; \mathrm{p}=0,012)$. Sementara itu, tidak terdapat perubahan nilai kemerahan/ kehijauan dan nilai kekuningan/kebiruan pada semua kelompok pasta gigi pemutih ( $p>0,05)$. Pada pasta gigi tanpa pemutih tidak didapatkan perubahan nilai kecerahan, nilai kemerahan/kehijauan, dan nilai kekuningan/ kebiruan yang bermakna ( $\mathrm{p}>0,05)$.

Perbandingan efektivitas terhadap perubahan warna gigi dianalisis dengan cara membandingkan rerata selisih nilai kecerahan, selisih nilai kemerahan/kehijauan, selisih nilai kekuningan/kebiruan, dan total perubahan warna antar kelompok. Tabel 2 memperlihatkan perbandingan efektivitas terhadap perubahan warna gigi.

\section{BAHASAN}

Hasil penelitian ini mendapatkan bahwa terdapat peningkatan nilai kecerahan warna gigi ekstrinsik pada gigi yang mendapatkan perlite $7 \%$, silica hydrated, dan sodium bicarbonate. Hasil analisis menunjukkan bahwa peningkatan nilai kecerahan tersebut bermakna secara statistik $(\mathrm{p}=0,01 ; \mathrm{p}=0,001$; $\mathrm{p}=0,012$ ). Pada pasta gigi tanpa pemutih, didapatkan adanya peningkatan nilai kecerahan juga, tetapi peningkatannya tidak bermakna secara statistik $(\mathrm{p}=0,087)$. Selain itu terdapat penurunan atau stagnansi nilai kemerahan/kehijauan disertai peningkatan atau stagnansi nilai kekuningan/kebiruan pada semua kelompok pasta gigi pemutih. Namun demikian, perubahan nilai kemerahan/kehijauan dan nilai kekuningan/ kebiruan tersebut tidak bermakna secara statistik $(\mathrm{p}>0,05)$.

Hasil penelitian ini menunjukkan bahwa pasta gigi pemutih yang mengandung perlite $7 \%$, silica hydrated, atau sodium bicarbonate efektif untuk meningkatkan kecerahan warna gigi ekstrinsik, tetapi tidak berpengaruh terhadap perubahan warna kemerahan/kehijauan, kekuningan/kebiruan, dan perubahan warna total gigi ekstrinsik.

Tabel 1. Gambaran rerata perubahan warna gigi

\begin{tabular}{lcccccc}
\hline \multicolumn{1}{c}{ Kelompok } & $\begin{array}{c}\text { Rerata } \\
\mathbf{A L}\end{array}$ & $\mathbf{p}$ & $\begin{array}{c}\text { Rerata } \\
\mathbf{\Delta a}\end{array}$ & $\mathbf{p}$ & $\begin{array}{c}\text { Rerata } \\
\mathbf{\Delta b}\end{array}$ & $\mathbf{p}$ \\
\hline Perlite 7\% & 1,17 & 0,01 & 37,67 & 0,077 & 10,00 & 0,059 \\
Silica hydrated & 0,50 & 0,001 & 39,17 & 0,083 & 9,50 & 0,257 \\
Sodium bicarbonate & 2,33 & 0,012 & 34,83 & 0,059 & 9,83 & 0,059 \\
Tanpa pemutih & 2,17 & 0,087 & 34,33 & 0,063 & 9,50 & 0,066 \\
\hline
\end{tabular}

Tabel 2. Perbandingan efektivitas terhadap perubahan warna gigi

\begin{tabular}{lc}
\hline \multicolumn{1}{c}{ Variabel } & Nilai p \\
\hline Nilai kecerahan & 1,000 \\
Nilai kemerahan/kehijauan & 0,102 \\
Nilai kekuningan/kebiruan & 0,361 \\
Total perubahan warna & 0,209
\end{tabular}


Setelah mengetahui bahwa pasta gigi pemutih efektif digunakan untuk meningkatkan kecerahan warna gigi ekstrinsik, penelitian ini kemudian membandingkan efektivitas dari tiap pasta gigi pemutih tersebut untuk mengetahui pasta gigi pemutih dengan kandungan apa yang paling efektif untuk meningkatkan kecerahan gigi. Hasil analisis menunjukkan bahwa tidak terdapat perbedaan rerata selisih nilai kecerahan, selisih nilai kemerahan/kehijauan, selisih nilai kekuningan/kebiruan, dan total perubahan warna antar kelompok $(\mathrm{p}>0,05)$. Hal ini menunjukkan bahwa efektivitas tiap pasta gigi pemutih tidak berbeda secara bermakna. Dengan kata lain, pasta gigi pemutih dengan kandungan perlite $7 \%$, silica hydrated, dan sodium bicarbonate memiliki efektivitas yang sama terhadap perubahan kecerahan dan warna gigi ekstrinsik.

Hasil penelitian ini sejalan dengan penelitian yang dilakukan oleh Fibryanto. ${ }^{7}$ Penelitian eksperiemntal tersebut bertujuan untuk menganalisis efektitifitas pasta gigi pemutih terhadap gigi yang berubah warna karena kopi. Pasta gigi pemutih yang digunakan pada penelitian tersebut merupakan pasta gigi yang mengandung perlite $7 \%$, speedy whitening agent, dan microcleansing crystal. Hasil penelitian tersebut mendapatkan bahwa pasta gigi pemutih efektif terhadap perubahan warna gigi ekstrinsik karena kopi. Pasta gigi pemutih dengan kandungan perlite merupakan pasta gigi yang paling efektif.

Hasil penelitian ini juga didukung oleh penelitian yang dilakukan oleh Hashemikamangar. ${ }^{8}$ Penelitian eksperimental tersebut bertujuan untuk menilai pengaruh pasta gigi pemutih terhadap stabilitas warna resin komposit microhybrid, nanofilled dan microfilled, serta semen resin-modified glass ionomer (RMGI). Penelitian tersebut menggunakan banyak jenis pasta gigi, antara lain yang serupa dengan penelitian ini yaitu pasta gigi dengan hydrated silica dan sodium bicarbonate. Hasil penelitian tersebut mendapatkan bahwa perubahan warna semua sampel komposit tidak terlihat secara klinis yang menunjukkan bahwa pasta gigi yang diuji tidak menyebabkan perubahan warna material komposit yang bermakna.

Hasil penelitian ini juga sejalan dengan penelitian oleh $\mathrm{Nam}^{9}$ yaitu suatu penelitian eksperiemntal yang bertujuan untuk mengevaluasi pengaruh penggunaan pasta gigi pemutih terhadap pemutihan gigi dan kandungan mineralnya. Pasta gigi pemutih yang digunakan pada penelitian tersebut merupakan pasta gigi yang mengandung hydrated silica dan sodium bicarbonate. Hasil penelitian $\mathrm{Nam}^{9}$ mendapatkan bahwa pasta gigi pemutih memberikan efek pemutihan gigi yang efektif, dan efektivitasnya akan meningkat seiring waktu penggunaan. Selain itu, dilaporkan juga bahwa aplikasi pasta gigi pemutih tidak merusak email gigi.

Kopi, teh, dan anggur, serta semua makanan yang menyebabkan noda gigi, merupakan makanan yang mengandung noda coklat tua yang ketika dikombinasikan dengan pelikel dari protein dapat menjadi awal mula pembentukan plak di permukaan gigi, sehingga menyebabkan perubahan warna gigi. Selain itu, zat pewarna ini memiliki komponen polifenol yang mengandung banyak ikatan rangkap. Ketika komponen polifenol ini berikatan dengan pelikel yang diperoleh dari protein, ditambah adanya agregasi bakteri serta pengerasan oleh kalsium dan fosfor air liur, akan terbentuk noda pada gigi yang sulit untuk dihilangkan dengan sikat gigi dan pasta gigi sederhana. ${ }^{10}$ Kandungan perlite dan sodium bicarbonate pada pasta gigi pemutih memiliki sifat abrasif, sehingga dapat membantu menghilangkan noda yang menempel pada gigi tersebut. ${ }^{9}$ Sementara itu, hydrated silica memiliki kekuatan jaringan yang baik, sehingga dapat secara efektif menghilangkan zat pewarnaan pada gigi dengan meningkatkan kekuatan pembersihan fisik ketika tekanan yang sama diaplikasikan ke gigi saat menyikat gigi. ${ }^{10}$

Keterbatasan penelitian ini ialah penelitian dilakukan secara in vitro sehingga hasil yang didapat bisa saja berbeda jika penelitiannya dilakukan secara in vivo. Selain itu, usia sampel gigi yang tidak terkontrol karena penulis mendapatkan sampel gigi dari tempat praktik, puskesmas dan rumah sakit sehingga tidak mempertim- 
bangkan lama waktu perendaman dalam alkohol yang mungkin memengaruhi efektivitas dari pasta gigi yang digunakan.

\section{SIMPULAN}

Pasta gigi pemutih efektif terhadap perubahan warna gigi ekstrinsik.

\section{Konflik Kepentingan}

Penulis menyatakan tidak terdapat konflik kepentingan dalam studi ini.

\section{DAFTAR PUSTAKA}

1. Goulart M de A, Condessa AM, Hilgert JB, Hugo FN, Celeste RK. Concerns about dental aesthetics are associated with oral health related quality of life in Southern Brazilian adults. Cienc e Saude Coletiva. 2018;23(11):3957-62.

2. Isiekwe GI, Aikins EA. Self-perception of dental appearance and aesthetics in a student population. Int Orthod. 2019; 17(3):506-12.

3. Bersezio C, Martín J, Mayer C, Rivera O, Estay $\mathrm{J}$, Vernal R, et al. Quality of life and stability of tooth color change at three months after dental bleaching. Qual Life Res. 2018;27(12):1-2.

4. da Costa AC, Rodrigues FS, de Fonte PP,
Rosenblatt A, Innes NPT, Heimer MV. Influence of sense of coherence on adolescents' self-perceived dental aesthetics; a cross-sectional study. BMC Oral Health. 2017;17(1):4.

5. Marheni IGA. Persepsi mahasiswa PSPDG Fakultas Kedokteran Universitas Udayana terhadap senyum dan estetika gigi. Bali Dent J. 2017;1(1):1.

6. Pritia MA. Pengaruh aplikasi cairan jeruk lemon dibandingkan pasta dengan pe-mutih terhadap perubahan warna gigi [Undergraduate Thesis]. Semarang: Universitas Islam Sultan Agung; 2017.

7. Fibryanto E. Efektivitas pasta gigi pemutih terhadap perubahan warna gigi ekstrinsik. JKGT. 2019;1(2):5-7.

8. Hashemikamangar SS, Hoseinpour F, Kiomarsi N, Dehaki MG, Kharazifard MJ. Effect of an optical whitening toothpaste on color stability of tooth-colored restorative materials. Eur J Dent. 2020; 14(1):85-91.

9. Nam S. Effects of whitening toothpaste on color. Biomed Res. 2017;28(9):25-32.

10. Cho MJ. The tooth whitening effect of toothpaste containing high cleaning silica and sodium hexametaphosphate and the preventive effect of staining by coffee, tea and wine. Int J Clin Prev Dent. 2020;16(4):192-9. 